\title{
A New Potyvirus sp. Infects Verbena Exhibiting Leaf Mottling Symptoms
}

Jennifer Kraus, Stephanie Cleveland, and Melodie L. Putnam, Department of Botany and Plant Pathology, Oregon State University, Corvallis 97331; Karen E. Keller and Robert R. Martin, Horticultural Crops Research Laboratory, United States Department of Agriculture-Agricultural Research Service, Corvallis, OR 97330; and Ioannis E. Tzanetakis, Department of Plant Pathology and Cell and Molecular Biology Program, Division of Agriculture, University of Arkansas, Fayetteville 72701

\begin{abstract}
Kraus, J., Cleveland, S., Putnam, M. L., Keller, K. E., Martin, R. R. and Tzanetakis, I. E. 2010. A new Potyvirus sp. infects verbena exhibiting leaf mottling symptoms. Plant Dis. 94:11321136.

Verbena 'Taylortown Red' plants showed virus-like mottling symptoms. Virus purifications disclosed the presence of elongated and spherical particles, evidence of mixed virus infections, whereas double-stranded RNA analysis revealed the presence of several bands absent in healthy plants. After shotgun cloning, three viruses were identified in 'Taylortown Red': Broad bean wilt virus-1, Coleus vein necrosis virus, and a previously undescribed potyvirus. Given the importance of verbena to the ornamental industry, we studied the viruses found in 'Taylortown Red' and, in this article, we present our findings on the new potyvirus, provisionally named Verbena virus Y (VVY). VVY belongs to the Potato virus $Y$ subgroup in the genus Potyvirus, has solanaceous plants, including potato, as alternative hosts, and can be transmitted by a ubiquitous pest in the ornamental industry, the green peach aphid.
\end{abstract}

Ornamentals, worldwide, are a multibillion-dollar industry. Many commercially valuable plant species are clonally propagated, which heightens the risk of the accumulation of undetected viruses during propagation. This can lead to significant losses because of undesirable changes in the plant phenotype. Verbena (Verbena $\times$ hybrida) is a popular ornamental propagated from cuttings, in which several new viruses and viroids have been identified in recent years $(4,6,9,13,28,29)$.

Verbena 'Taylortown Red' plants displaying mottling symptoms (Fig. 1) were examined for the possibility of viral infection. Virus and double-stranded RNA (dsRNA) purifications disclosed the presence of multiple viruses in Taylortown Red. Shotgun cloning followed by sequencing revealed three viruses infecting 'Taylortown Red': Broad bean wilt virus-1 (BBWV-1), Coleus vein necrosis virus (CVNV; 27 ) and a new Potyvirus sp., provisionally named Verbena virus Y (VVY), the subject of this article.

Members of the family Potyviridae are the most abundant plant viruses, with sev-

Corresponding author: I. E. Tzanetakis

E-mail: itzaneta@uark.edu

* The $\boldsymbol{e}$-Xtra logo stands for "electronic extra" and indicates that Figure 1 appears in color in the online edition.

Accepted for publication 3 June 2010.

doi:10.1094/PDIS-94-9-1132

(c) 2010 The American Phytopathological Society eral hundred members identified to date. They can be transmitted mechanically, by seed, pollen, or vectors, including aphids, whiteflies, eriophyid mites, or plasmodiophorids. The mode of transmission of potyviruses and the vast number of potential vectors for VVY, in combination with the vegetative propagation of verbena, made characterization of this virus a necessity. Here, we present the sequence of the virus, detection protocols, and potential plant host and aphid vector species.

\section{MATERIALS AND METHODS}

Virus and nucleic acid purifications. Virus purification was performed according to the Martin and Bristow (26) protocol. The procedure was repeated twice, with and without a $20 \%$ sucrose cushion during the ultraspeed centrifugations. Purified virus preparations were stained with
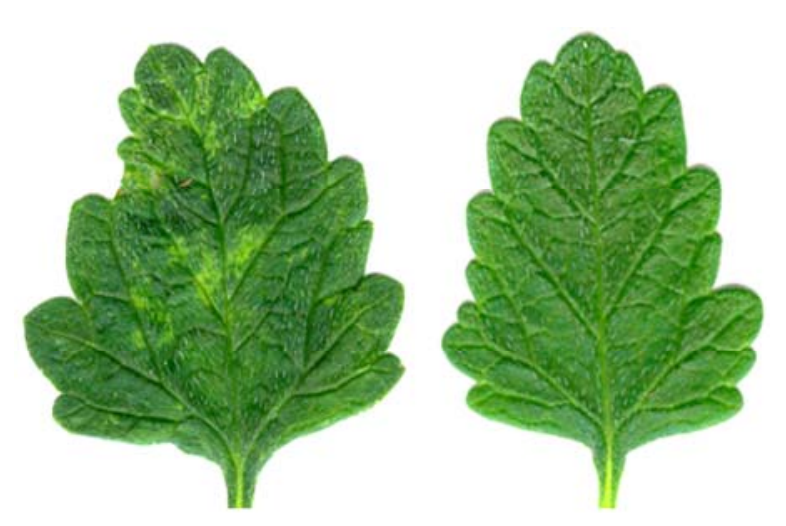

Fig. 1. Symptoms of verbena 'Taylortown Red' infected with Verbena virus Y, Broad bean wilt virus-1, and Coleus vein necrosis virus. Left: infected and right: healthy material. obtain the sequence of the gaps between potyvirus contigs obtained from shotgun cloning (38). The $5^{\prime}$ end of the virus was obtained using random amplification of cDNA ends (RACE) after two tailing reactions using different nucleotides (37). The genome sequence, representing at least a $3 \times$ genome coverage, was assembled using CAP3 (16) and deposited in GenBank under accession number EU564817.

The putative cleavage sites of the polyprotein were identified using PredictProtein (30) and ClustalW (32), as well as comparison of the VVY putative cleavage sites to those of other potyviruses (1). Similarities between VVY protein orthologs were calculated using Gatmat at default settings (7). Phylogenetic analysis was performed with ClustalW (32) using the neighbor-joining algorithm, Kimura's
$2 \%$ ammonium molybdate and viewed using a Philips CM-12 scanning transmission electron microscope. DsRNA extractions were performed using a modified Yoshikawa and Converse (42) protocol. Total RNA for reverse-transcription polymerase chain reaction (RT-PCR) detection purposes was extracted as previously reported (35).

Cloning, genome sequence, and analysis. Purified virus single-stranded RNA or dsRNA were used as template to obtain the sequence of VVY, with cloning and sequencing performed as described previously (36). BLAST was used to identify clones carrying virus sequences (3). Oligonucleotide primers were developed and used in RT-PCR amplification to

1132 Plant Disease /Vol. 94 No. 9 
correction, and bootstrap consisting of 1,000 pseudoreplicates.

Detection. Three immunological techniques were used for VVY detection; Western blot, dot blot, and triple-antibody sandwich enzyme-linked immunosorbent assay (ELISA). Western blot and dot blot were performed using universal Potyvirus (Agdia, Elkhart, IN) and Potato virus $Y$ (PVY) polyclonal (Phyto Diagnostics Co. Ltd,. North Saanich, BC, Canada) antibodies whereas, for ELISA, PVY polyclonal and monoclonal antibodies (Phyto Diagnostics Co. Ltd.) were used. VVY-infected 'Taylortown Red', healthy 'Twilight Blue with Eye', and pepper tissue infected with Tobacco etch virus were used in the tests. Western blots were performed as previously described (33). For dot blot, leaf tissue was ground in phosphate-buffered saline (PBS), pH 7.4 (137 mM NaCl, 2.7 $\mathrm{mM} \mathrm{KCl}, 8 \mathrm{mM} \mathrm{Na} \mathrm{HPO}_{4}$, and $2 \mathrm{mM}$ $\mathrm{KH}_{2} \mathrm{PO}_{4}$ ), and blotted on a nitrocellulose membrane using the Bio-Rad Bio-Dot microfiltration apparatus. After a brief wash with PBS, the protocol described by Tzanetakis et al. (34) for tissue blot was used. Buffers described by Clark and Adams (9) were used in a triple-antibody sandwich ELISA. A polyclonal antibody was used for capture and a monoclonal antibody was used in detection as per the manufacturer's recommendation. Rabbit anti-mouse alkaline phosphatase conjugate (Jackson Immuno Research, West Grove, PA) at $0.3 \mu \mathrm{g} / \mathrm{ml}$ was added after the monoclonal antibody. Following the final washing step, $p$-nitrophenyl phosphate (Sigma-Aldrich, St. Louis) was added at $0.5 \mathrm{mg} / \mathrm{ml}$. The colorimetric reaction was developed for $1 \mathrm{~h}$ at room temperature and the optical density with absorbance at 405 $\mathrm{nm}$ was determined using a BioTek plate reader (BioTek, Winooski, VT).

Primers VVYF (5' CCATTCGAAAAC TTCGAGGA) and VVYR (5' GCTTCG AGTCGATTTTCAGG) that amplify a 289-bp region of the VVY genome were selected for RT-PCR detection. BBWV-1 detection was done using primers BBWVF (5'-CTTCATGGCTCCCTTGCAT) and BBWVR (5'-CAATCACACTCATCAAGC CAA) whereas primers CVNVF (5'TAAGGGTGACACTTCGGATG) and CVNVR (5'-CGCAATGTGCTAACTTCA CG) (24) were used for detection of CVNV. The quality of RNA of all samples was tested with primers ICF/ICR (39). The PCR program on a Strategene Robocycler using Genescript Taq polymerase consisted of denaturation for $3 \mathrm{~min}$ at $94^{\circ} \mathrm{C}$; followed by 40 cycles at 94,56 , and $72^{\circ} \mathrm{C}$ for $30 \mathrm{~s}$ each; and terminated with $5 \mathrm{~min}$ of incubation at $72^{\circ} \mathrm{C}$. At least 10 amplicons were sequenced and all were VVY specific, validating the protocol.

Transmission. VVY host range was determined after mechanical inoculation using 'Taylortown Red' tissue homogenized in PBS (1:10 wt/vol) and rubbed onto 600-grit Carborundum-dusted leaves. The inoculated species were: Brassica rapa var. rapa, Chenopodium quinoa, curbita pepo, Gomphrena globosa, Solanum lycopersicum, Nicotiana benthamiana, $N$. sanderae, $S$. tuberosum, Spinacea oleracea, and Vigna unguiculata subsp. dekindiana. In all, 5 to 10 plants of each species were inoculated and tested for VVY transmission using RT-PCR about 1 month post inoculation. The green peach aphid (GPA; Myzus persicae Sulz.) was tested as a vector of VVY. A colony was established in an insect-proof cage on a dsRNA-free and BBWV-1, CVNV, and VVY RT-PCR-negative 'Twilight Blue with Eye' verbena. Apterous individuals were transferred to 'Taylortown Red'infected material, where they fed for approximately $16 \mathrm{~h}$. A group of at least 20 individuals were placed on 'Twilight Blue with Eye' plants and left to feed for 7 days before the application of a systemic insecticide. Two experiments for a total of 10 plants were performed and plants were tested for VVY, BBWV-1, and CVNV 1 month after the application of the insecticide.

\section{RESULTS}

VVY characterization. Unusual symptoms observed on Taylortown Red plants led us to investigate the possibility of a virus infection. Analysis of dsRNA extracts disclosed the presence of multiple bands and, through shotgun cloning, Kraus et al. (21) identified BBWV-1, CVNV, and a new potyvirus. We performed purifications in an effort to separate the viruses but they always co-purified, as indicated by the spherical and flexuous elongated particles observed under the electron microscope. Using RT-PCR, we verified purification of all three viruses (data not shown).

A combination of shotgun cloning, RTPCR, and RACE was used to obtain the genome of VVY. The virus genome is 9,742 nucleotides (nt) excluding the A-tail and is most similar to isolates of PVY and Pepper mottle virus (PepMoV), sharing $63 \%$ nucleotide identity over the length of the genomes. The percent identity between Capsicum annum, Cucumis sativus, Cu-

VVY and other potyviruses indicates that VVY is a new potyvirus (2).

The highly unstructured 134-nt $5^{\prime}$ untranslated region (UTR) (dG $<-6.6$ $\mathrm{kcal} / \mathrm{mol}$; 40) probably accommodates easy access of the ribosomes to the putative start codon of the polyprotein, which is in excellent translational context $(19,24)$. The putative 3,105-amino-acid (aa) polyprotein has a molecular mass of $352 \mathrm{kDa}$. The putative cleavage sites of the polyprotein and mass of the mature proteins are listed in Table 1. The first 285 aa of the polyprotein is the VVY P1 serine protease ortholog, the least-conserved region of the potyviral polyprotein (2). VVY P1 shows the highest similarity with PVY and Potato virus V (PVV) orthologs; with about $40 \%$ amino acid sequence identity and between 56 and 58\% similarity. The protein contains conserved P1 motifs between residues 193 and 261, including the catalytic protease residues $\mathrm{His}_{193}-\mathrm{Asp}_{202}-\mathrm{Ser}_{236}$ $(1,41)$.

The 456-aa helper component serine protease (HC-Pro) is found downstream of $\mathrm{P} 1$ and contains all signature HC-Pro Potyvirus motifs (40), including the tetrapeptide $\mathrm{KMTC}_{50-53}$, involved in virus-host interactions and essential for vector transmission, and the tripeptides $\mathrm{ING}_{248-250}$, $\mathrm{CCC}_{290-292}$, and $\mathrm{PTK}_{308-310}$, involved in genome amplification, systemic movement, and vector transmission, respectively. The protease active site residues are $\mathrm{Cys}_{342}$ and $\mathrm{His}_{415}$. The protein is related most closely to the HC-Pro of PVY and Pepper severe mosaic virus (PSMV), with $67 \%$ amino acid sequence identity and $82 \%$ similarity. The 390 -aa P3 is one of the least conserved Potyvirus proteins and functions as a pathogenicity and host determinant $(15,31)$. The VVY P3 shows about $40 \%$ amino acid sequence identity (60\% similarity) to the PVY and PSMV orthologs. The slippery conserved sequence $\mathrm{G}_{2} \mathrm{~A}_{6(2943-2949)}$ was identified at the $5^{\prime}$ end of the putative VVY pretty interesting Potyviridae open reading frame (PIPO; 8) whereas the PIPO stop codon is located at nucleotides 3,188 to 3,190 . A 52 -aa peptide downstream $\mathrm{P} 3$ is the $6 \mathrm{~K} 1$ ortholog of VVY and is most similar to that of the PepMoV and PVV counterparts

Table 1. Location of the putative cleavage sites and molecular mass of Verbena virus Y proteins

\begin{tabular}{lccl}
\hline Protein & $\begin{array}{c}\text { Molecular mass } \\
(\mathbf{k D a})\end{array}$ & Protein coordinates & $\begin{array}{c}\text { Cleavage site } \\
\text { (amino acid sequence -4/+3) }\end{array}$ \\
\hline P1 & 32.4 & $1-285$ & P1/HC-Pro (MQQF/SNA) \\
HC-Pro & 51.7 & $286-741$ & HC-Pro/P3 (YRMG/GLL) \\
P3 & 44.2 & $742-1,131$ & HC-Pro/P3 (VEHQ/KND) \\
P3N/PIPO & 31.4 & $\ldots$ & $\ldots$ \\
6K1 & 6.0 & $1,132-1,183$ & $6 \mathrm{~K} 1 / \mathrm{CI}(\mathrm{VHHQ} / \mathrm{LDD})$ \\
CI & 71.1 & $1,184-1,817$ & $\mathrm{CI} / 6 \mathrm{~K} 2$ (VHHQ/STG) \\
6K2 & 5.7 & $1,818-1,869$ & $6 \mathrm{~K} 2 / \mathrm{Vpg}$ (VSHQ/GKR) \\
Vpg & 21.5 & $1,870-2,057$ & Vpg/NIa (VEHE/SKS) \\
NIa & 28.0 & $2,058-2,303$ & NIa/NIb (VQEQ/GLS) \\
NIB & 60.0 & $2,304-2,822$ & $\ldots$ \\
CP & 31.8 & $2,823-3,105$ & NIb/CP (VSHQ/AEE) \\
\hline
\end{tabular}


with 73 and $67 \%$ amino acid sequence identity ( 88 and $83 \%$ similarity), respectively. The 634-aa virus helicase, the cylindrical inclusion body protein $(\mathrm{CI})$, includes signature RNA helicase motifs between residues 79 and 360 (25). The protein is closely related to the CI proteins of Wild potato mosaic virus (WPMV), Peru tomato mosaic virus (PTMV), PVV, and PVY, with about $70 \%$ amino acid sequence identity and over $80 \%$ similarity. A second 52-aa peptide is found downstream of CI and contains a transmembrane domain between residues 20 and 42 (22). Orthologs of this protein $(6 \mathrm{~K} 2)$ anchor the virus replication complex to the membranes of the endoplasmic reticulum (40). The most similar proteins in the database are the 6K2 peptides of PSMV and PVY, with 57 and $53 \%$ amino acid sequence identity ( 75 and $81 \%$ similarity), respectively. The 188-aa genome-linked protein $(\mathrm{Vpg})$ is most similar to the orthologous proteins of PepMoV and WPMV, with 82 and $78 \%$ amino acid sequence identity and $89 \%$ similarity, respectively. The third protease of the virus, the 246-aa nuclear inclusion bodies A protein (NIa), is more similar to the NIa of PepMoV and PVY, with about $69 \%$ amino acid sequence identity (84 and $81 \%$ amino acid similarity), respectively, and contains the $\mathrm{His}_{48}$ - $\mathrm{Asp}_{83^{-}}$ $\mathrm{Cys}_{151}$-His 167 cysteine protease catalytic tetrad. The 519-aa virus polymerase, nuclear inclusion body B protein (NIb), is the most conserved protein of potyviruses and contains the eight conserved motifs identified by Koonin (20) between residues 180 and 431. VVY NIb is related more closely to the NIb of PTMV, with $73 \%$ and PepMoV, PVY, and PSMV with $70 \%$ amino acid sequence identity, whereas the similarity to all four viruses exceeds $85 \%$. The 283-aa coat protein (CP) is related most closely to the CPs of PVY and PepMoV, with 80 and $73 \%$ amino acid sequence identity and 89 and $82 \%$ similarity, respectively. The protein contains the characteristic DAG $_{8-10}$ motif involved in aphid transmission (5). The $\operatorname{Arg}_{173}$ and Asp 217 residues are probably involved in the assembly process of virus particles $(11,17)$. The $3^{\prime}$ UTR of the virus is $290 \mathrm{nt}$ long, excluding the A-tail. Phylogenetic analysis of the polymerase conserved motifs and the $\mathrm{CP}$ of members of all recognized genera of the family Potyviridae clearly places the virus within the PVY subgroup in the genus Potyvirus (Fig. 2).

Detection. VVY was detected successfully with the three immunological techniques using universal Potyvirus mono- clonal (18) or PVY-specific polyclonal antibodies (Fig. 3). In the ELISA test, performed twice, VVY-infected material typically gave readings that were at least five times higher than the control when using PVY polyclonal antibodies and more than twice the readings of the control using Potyvirus monoclonal antibodies. The virus was detected by RT-PCR after 30 cycles, although we chose to use 40 cycles for routine detection because the VVYF/VVYR primers produced no background at the higher number of PCR cycles (Fig. 4).

Transmission. Several herbaceous plants were tested as potential alternate hosts of VVY and, given the similarity of the virus to PVY, one of the most important viruses for agriculture worldwide, we included several solanaceous hosts in our studies. $N$. benthamiana $(6 / 10)$ and $S$. tuberosum (2/8) were confirmed as hosts of VVY by RT-PCR and sequencing of the amplification products. Plants of both species were stunted compared with buffer control plants. The ability of the GPA to transmit the virus was also tested. The aphid is a vector for VVY, with one of the test plants becoming infected, as verified by RT-PCR amplification of the virus and sequencing of the products (Fig. 4).
A

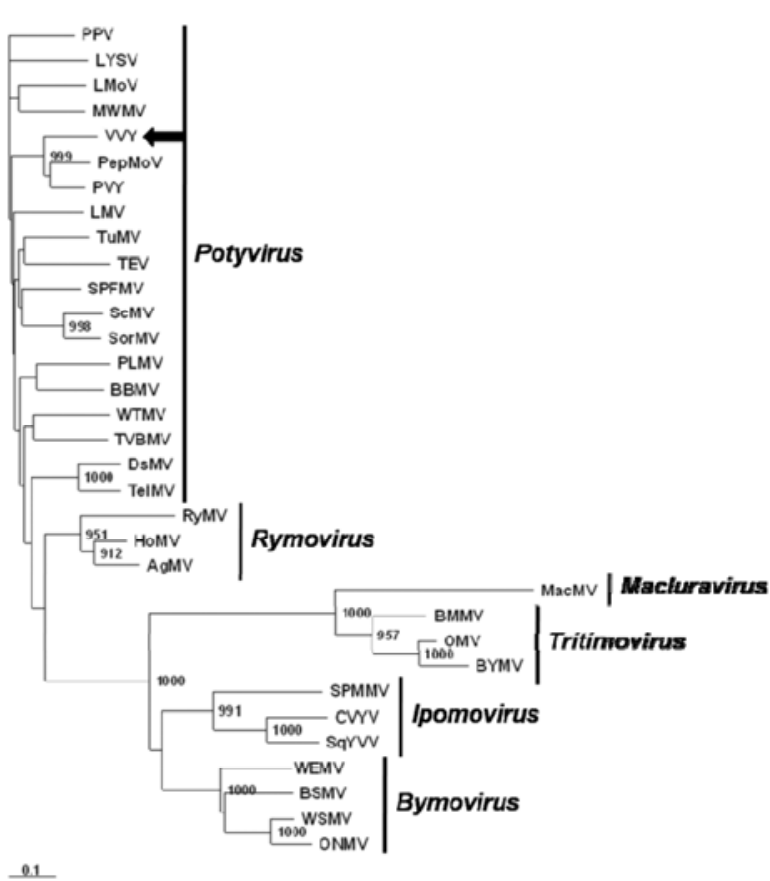

B

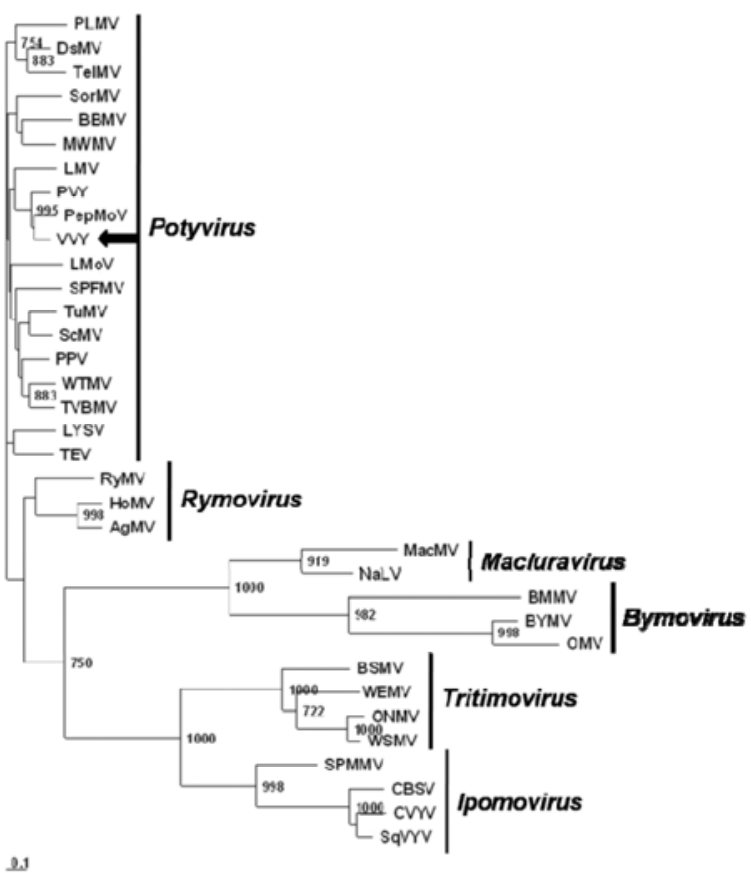

Fig. 2. Unrooted phylograms of the A, polymerase conserved motifs and B, coat protein (B) of Verbena virus $Y$ and other potyviruses. Sequences used for the construction of the phylogram were obtained from the GenBank accessions of the complete genome of the viruses unless otherwise noted. Agropyron mosaic virus, AgMV; Banana bract mosaic virus, BBMV; Barley mild mosaic virus, BMMV; Barley yellow mosaic virus, BYMV; Brome streak mosaic virus, BSMV; Cassava brown streak virus, CBSV, GenBank accession number AF311052; Cucumber vein yellowing virus, CVYV; Dasheen mosaic virus, DsMV; Hordeum mosaic virus, HoMV; Leek yellow stripe virus, LYSV; Lettuce mosaic virus, LMV; Lily mottle virus, LMoV; Maclura mosaic virus, MacMV, GenBank accession number U58771; Moroccan watermelon mosaic virus, MWMV; Narcissus latent virus, NaLV, GenBank accession number U58770; Oat mosaic virus, OMV; Oat necrotic mottle virus, ONMV; Peace lily mosaic virus, PLMV; Pepper mottle virus, PepMoV; Plum pox virus, PPV; Potato virus Y, PVY; Ryegrass mosaic virus, RyMV; Scallion mosaic virus, ScMV; Sorghum mosaic virus, SorMV; Squash vein yellowing virus, SqYVV; Sweet potato feathery mottle virus, SPFMV; Sweet potato mild mottle virus, SPMMV; Telosma mosaic virus, TelMV; Tobacco etch virus, TEV; Tobacco vein banding mosaic virus, TVBMV; Turnip mosaic virus, TuMV; Verbena virus Y, VVY; Wheat eqlid mosaic virus, WEMV; Wheat streak mosaic virus, WSMV; Wild tomato mosaic virus, WTMV. Numerical values of the nodes with bootstrap values of less than $70 \%$ are not shown, as they are not considered significant. The bars represent 0.1 amino acid changes per site. 


\section{DISCUSSION}

Virus-like mottling symptoms were observed on 'Taylortown Red' plants. A study was initiated to detect the virus or viruses observed symptoms. Three viruses were found in all symptomatic 'Taylortown Red' clonal propagation of verbena. We have studied and characterized two of the viruses, CVNV (21) and VVY. VVY was characterized and the complete nucleotide sequence was obtained. VVY is a new Potyvirus, belonging to one of the most important groups of plant viruses for agriculture and floriculture, the PVY subgroup.

The close relationship of VVY to PVY led to the investigation of the serological relationships between the two viruses. Monoclonal universal Potyvirus antibodies readily detected the virus but, most importantly, polyclonal antibodies against PVY cross-reacted very strongly to VVY. Those findings suggest that VVY could have been mislabeled as PVY in verbena or other hosts thought to be infected by PVY. We tested the hypothesis that VVY can infect important solanaceous hosts by testing transmission of the virus to potato, tomato, pepper, and Nicotiana spp. Potato and Nicotiana spp. were found to be experimental hosts for the virus, and plants infected with the virus exhibited stunting.

GPA is a cosmopolitan pest and a vector of a number of potyviruses. These properties made it an excellent candidate to verify aphid transmissibility of VVY, a property deduced by phylogenetic analysis and that could be associated with or cause the plants. This was not a surprise given the the motifs present in HC-Pro and CP. GPA

is also one of the most noxious pests in greenhouse settings because it has developed resistance to a number of insecticides (13), making it a potentially important disseminator of the virus if verified as a VVY vector. VVY-infected material remained asymptomatic for a period of more than 2 years. Transmission rate was low but these experiments verified that VVY is aphid transmissible and, depending on the virus isolate, aphid clone, and optimal acquisition access period $(12,23)$ on infected verbena, it can potentially be an important vector for the virus in greenhouse settings. The latency of the VVY infection indicates that symptoms on Taylortown Red are caused by BBWV-1, CVNV, or the synergy between the viruses. The presence and distribution of VVY in verbena is unknown but, given the serological relationship of VVY with PVY, it is possible that plants thought to be infected with PVY are truly infected with VVY.

\section{ACKNOWLEDGMENTS}

This study is dedicated to the late Dr. Jennifer Kraus, who initiated this project but was unable to complete it due to an incurable illness. The National Floral Research Initiative and start-up funds provided by the Arkansas Agricultural Experiment Station to I. E. Tzanetakis funded this work.

\section{LITERATURE CITED}

1. Adams, M. J., Antoniw, J. F., and Beaudoin, F. 2005. Overview and analysis of the polyprotein cleavage sites in the family Potyviridae. Mol. Plant Pathol. 6:471-487.

2. Adams, M. J., Antoniw, J. F., and Fauquet, C. M. 2005. Molecular criteria for genus and species discrimination within the family Potyviridae. Arch. Virol. 150:459-479.

3. Altschul, S. F., Madden, T. L., Schäffer, A. A., Zhang, J., Zhang, Z., Miller, W., and Lipman,

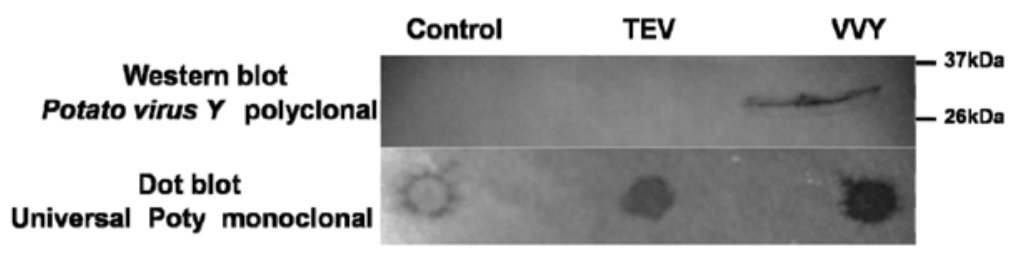

Fig. 3. Western and dot-blot detection of Verbena virus Y (VVY) using Potato virus $Y$ polyclonal or universal Potyvirus monoclonal antibodies. TEV: Tobacco etch virus, a potyvirus used to test antibody cross-reactivity. Control: healthy verbena tissue.

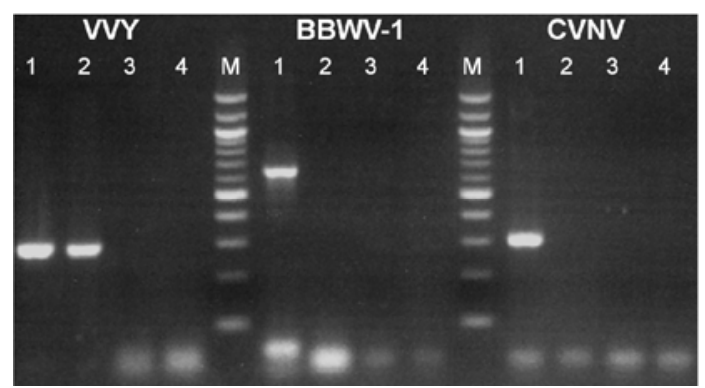

Fig. 4. Reverse transcription polymerase chain reaction detection verifying Verbena virus Y (VVY) transmission using the green peach aphid. BBWV-1: Broad bean wilt virus-1; CVNV: Coleus vein necrosis virus. Lane 1: 'Taylortown Red' infected with VVY, BBWV-1, and CVNV; lane 2: 'Twilight Blue with Eye' used in transmission study; lane 3: 'Twilight Blue with Eye' control; lane 4: water control.
D. J. 1997. Gapped BLAST and PSI-BLAST: a new generation of protein database search programs. Nucleic Acids Res. 25:3389-3402.

4. Assis Filho, F. M., Harness, A., Tiffany, M., Gera, A., Spiegel, S., and Adkins, S. 2006. Natural infection of verbena and phlox by a recently described member of the Carmovirus genus. Plant Dis. 90:1115.

5. Atreya, C. D., Raccah, B., and Pirone, T. P. 1990. A point mutation in the coat protein abolishes aphid transmissibility of a potyvirus. Virology 178:161-165.

6. Baker, C. A., Beckham, K., and Hiebert, E., 2004. A virus related to Clover yellow mosaic virus found east of the Mississippi River in Verbena Canadensis in Florida. Plant Dis. 88:223.

7. Campanella, J. J., Bitincka, L., and Smalley, J. 2003. MatGAT: an application that generates similarity/identity matrices using protein or DNA sequences. BMC Bioinf. 4:29.

8. Chung, B. Y.-W., Miller, W. A., Atkins, J. F., and Firth, A. E. 2008. An overlapping essential gene in the Potyviridae. Proc. Natl. Acad. Sci. USA 105:5897-5902.

9. Clark, M. F., and Adams, A. N. 1977. Characteristics of the microplate method of enzymelinked immunosorbent assay for the detection of plant viruses. J. Gen. Virol. 34:475-483.

10. Cohen, J., Zeidan, M., Feigelson, L., Maslenin, L., Rosner, A., and Gera, A. 2003. Characterization of a distinct carlavirus isolated from Verbena. Arch. Virol. 148:1007-1015.

11. Dolja, V. V., Boyko, V. P., Agranovsky, A. A., and Koonin, E. V. 1991. Phylogeny of capsid proteins of rod-shaped and filamentous RNA plant viruses, two families with distinct patterns of sequence and probably structure conservation. Virology 184:79-86.

12. Domier, L. L., Latorre, I. J., Steinlage, T. A., McCoppin, N., and Hartman, G. L. 2003. Variability and transmission by Aphis glycines of North American and Asian Soybean mosaic virus isolates. Arch. Virol. 148:1925-1941.

13. Georghiou, G. P., and Lagunes-Tejada, A. 1991. The Occurrence of Resistance to Pesticides in Arthropods. An Index of Cases Reported Through 1989. FAO, Rome

14. Guaragna, M. A., Jordan, R. L., and Putnam, M. L. 2004. First report of Bean yellow mosaic virus (Pea mosaic strain) in Verbena $\times$ hybrid. Plant Dis. 88:574

15. Hjulsager, C. K., Olsen, B. S., Jensen, D. M. Cordea, M. I., Krath, B. N., Johansen, I. E., and Lund, O. S. 2006. Multiple determinants in the coding region of Pea seed-borne mosaic virus $\mathrm{P} 3$ are involved in virulence against sbm2 resistance. Virology 355:52-61.

16. Huang, X., and Madan, A. 1999. CAP3: a DNA sequence assembly program. Genome Res. 9:868-877.

17. Jagadish, M. N., Huang, D., and Ward, C. W. 1993. Site-directed mutagenesis of a potyvirus coat protein and its assembly in Escherichia coli. J. Gen. Virol. 74:893-896.

18. Jordan, R., and Hammond, J. 1991. Comparison and differentiation of potyvirus isolates and identification of strain-, virus-, subgroupspecific and potyvirus group-common epitopes using monoclonal antibodies. J. Gen. Virol. 72:25-36

19. Joshi, C. P., Zhou, H., Huang, X., and Chiang, V. L. 1997. Context sequences of translation initiation codon in plants. Plant Mol. Biol. 35:993-1001.

20. Koonin, E. V. 1991. The phylogeny of RNAdependent RNA polymerases of positive-strand RNA viruses. J. Gen. Virol. 72:2197-2206.

21. Kraus, J., Tzanetakis, I. E., Putnam, M. L., and Martin, R. R. 2008. Complete nucleotide sequence of an isolate of coleus vein necrosis virus from verbena. Arch. Virol. 153:381-384.

22. Krogh, A., Larsson, B., von Heijne, B., and Sonnhammer, E. L. L. 2001. Predicting trans- 
membrane protein topology with a hidden Markov model: application to complete genomes. J. Mol. Biol. 305:567-580.

23. Lupoli, R., Labonne, G., and Yvon, M. 1992. Variability in the transmission efficiency of potyviruses by different clones of Aphis gossypii. Entomol. Exp. Appl. 65:291-300.

24. Lutcke, H. A., Chow, K. C., Mickel, F. S., Moss, K. A., Kern, H. F., and Scheele, G. A. 1987. Selection of AUG initiation codons differs in plants and animals. EMBO J. 6:43-48.

25. Marchler-Bauer, A., Anderson, J. B., Derbyshire, M. K., DeWeese-Scott, C., Gonzales, N. R., Gwadz, M., Hao, L., He, S., Hurwitz, D. I., Jackson, J. D., Ke, Z., Krylov, D., Lanczycki, C. J., Liebert, C. A., Liu, C., Lu, F., Lu, S., Marchler, G. H., Mullokandov, M., Song, J. S., Thanki, N., Yamashita, R. A., Yin, J. J., Zhang, D., and Bryant, S. H. 2007. CDD: a conserved domain database for interactive domain family analysis. Nucleic Acids Res. 35:D237-40.

26. Martin, R. R., and Bristow, P. R. 1988. A carlavirus associated with blueberry scorch disease. Phytopathology 78:1636-1640.

27. Mollov, D. S., Hayslette, M. C., Eichstaedt, K. A., Beckman, N. G., Daughtrey, M. L., and Lockhart, B. E. 2007. Identification and characterization of a carlavirus causing veinal necrosis of coleus. Plant Dis. 91:754-757.

28. Mumford, R. A., Jarvis, B., Harju, V., Elmore, J., and Skelton, A.2005. The first identification of two viruses infecting trailing verbena in the UK. Plant Pathol. 54:568.
29. Nie, X. Z., Singh, R. P., and Bosan, H. 2005. Molecular cloning, secondary structure, and phylogeny of three pospiviroids from ornamental plans. Can. J. Plant Pathol. 27:592602.

30. Rost, B., Yachda, G., and Li, J. 2004. The predict protein server. Nucleic Acids Res. 32:W321-326.

31. Suehiro, N., Natsuaki, T., Watanabe, T., and Okuda, S. 2004. An important determinant of the ability of Turnip mosaic virus to infect Brassica spp. and/or Raphanus sativus is in its P3 protein. J. Gen. Virol. 85:2087-2098.

32. Thompson, J. D., Higgins, D. G., and Gibson, T. J. 1994. CLUSTALW, improving the sensitivity of progressive multiple sequence alignment through sequence weighting, positionspecific gap penalties and weight matrix choice. Nucleic Acids Res. 22:4673-4680.

33. Tzanetakis, I. E. 2004. Molecular characterization of criniviruses and ilarviruses infecting strawberry. Ph.D. thesis, Oregon State University, Corvallis.

34. Tzanetakis, I. E., Halgren, A. B., Keller, K. E., Hokanson, S. C., Maas, J. L., McCarthy, P. L., and Martin, R. R. 2004. Identification and detection of a virus associated with strawberry pallidosis disease. Plant Dis. 88:383-390.

35. Tzanetakis, I. E., Halgren, A., Mosier, N., and Martin, R. R. 2007. Identification and characterization of Raspberry mottle virus, a novel member of the Closteroviridae. Virus Res. 127:26-33.
36. Tzanetakis, I. E., Keller, K. E., and Martin, R. R. 2005. The use of reverse transcriptase for efficient first and second strand cDNA synthesis from single and double-stranded RNA templates. J. Virol. Methods 124:73-77.

37. Tzanetakis, I. E., and Martin, R. R. 2004 Complete nucleotide sequence of a strawberry isolate of Beet pseudo-yellows virus. Virus Genes 28:239-246.

38. Tzanetakis, I. E., Postman, J. D., and Martin, R. R. 2005. A member of the Closteroviridae from mint with similarities to all three genera of the family. Plant Dis. 89:654-658.

39. Tzanetakis, I. E., Postman, J. D., and Martin, R. R. 2007. Identification, detection and transmission of a new Vitivirus from Mentha. Arch. Virol. 152:2027-2033.

40. Urcuqui-Inchima, S., Haenni, A. L., and Bernardi, F. 2001. Potyvirus proteins: a wealth of functions. Virus Res. 74:157-175.

41. Valli, A., López-Moya, J. J., and García, J. A. 2007. Recombination and gene duplication in the evolutionary diversification of $\mathrm{P} 1$ protein in the family Potyviridae. J. Gen. Virol. 88:1016-1028.

42. Yoshikawa, N., and Converse, R. H. 1990. Strawberry pallidosis disease: Distinctive dsRNA species associated with latent infections in indicators and in diseased strawberry cultivars. Phytopathology 80:543-548.

43. Zuker, M. 2003. Mfold web server for nucleic acid folding and hybridization prediction. $\mathrm{Nu}$ cleic Acids Res. 31:3406-3415. 